\title{
反転流れ場におけるトレーサー拡散に基づく環境污染物質の発生源同定 SOURCE IDENTIFICATION OF ENVIRONMENTAL POLLUTANTS BASED ON TRACER DISPERSION IN REVERSED FLOW FIELD
}

\author{
菊本英 紀*, 大岡龍三**, 加藤信介*** \\ Hideki KIKUMOTO, Ryozo OOKA and Shinsuke KATO
}

\begin{abstract}
This study presents a novel method for identifying the source of an environmental pollutant continuously released from a point source in a turbulent flow field at a statistically steady state. The method employs the analysis of tracer dispersion in a reversed flow field (RFF) released from observation points of the pollutant. The RFF is artificially produced from the forward flow field (FFF); the direction of temporal progress and velocity vectors are produced in the opposite direction to those in the FFF. Based on the probabilistic behavior of a virtual particle in the flow fields, we derived a symmetric property of the expected staying time (EST) of a pollutant and tracer particles in the FFF and RFF. The symmetry of the EST is an indication of the duality of the scalar fields, which states that a measured concentration of the pollutant and a distribution of the EST of the tracer give the estimated source strength as a function of the source position. When multiple observation points are available, the source position can be determined by the uniqueness of the estimated source strength at a point. This paper introduces the basic idea of the present method based on a physical consideration of the particle behavior in the RFF. An example of the source identification procedure is also presented for pollutant dispersion in a two-dimensional uniform flow field.
\end{abstract}

Keywords: Inverse problem, Turbulent dispersion, Particle behavior, Duality 逆問題, 乱流拡散, 粒子挙動, 双対関係

1. はじめに

都市・建築空間中においてある環境污染物質の濃度が検出された 場合、その物質の発生源（発生位置および強度）を迅速に特定でき れば、同物質の濃度や被害低減のための効果的な対応が可能となる。 しかし、流れ場や発生源の十分な情報が与えられ、その結果生じる 濃度分布を予測する順問題としての拡散解析に対し、結果としての 濃度計測值からその原因としての発生源を推定する発生源同定の問 題は、一般に逆問題の性質を示し適切な解を得るのが難しい1),2)。 発生源同定は、環境工学の様々な分野における普遍的な問題とし て、これまでにも多くの研究がなされてきた。拡散現象におけるガ ウス・プルームモデル 3)など発生源位置・強度と観測濃度との関係 が解析的に与えられる場合には、その方程式を逆に解くことで観測 濃度から発生源位置および強度を推定することができる。 $\left.\mathrm{Islam}^{4}\right)^{4}$ は 大気拡散、Ala $5^{5)}$ や Alapati, Kabala ${ }^{6}$ は地下水污染の問題において 解析的手法により発生源の同定を行っている。しかし、解析的関係 が得られるのは、一様流れ場など単純な状況に限られる。

発生源位置・強度と観測濃度との関係を利用する他の方法として、 最適化手法による発生源同定も検討されている。そこでは、考えら れる様々な発生条件と観測点での濃度応答との関係を事前に調べて
おき、実際に環境污染物質の濃度が計測された場合には、その観測 濃度と計算濃度との誤差を最小化するよう最適な発生源位置および 強度を探索する。例えば、Gorelick ら ${ }^{77}$ は地下水污染の 2 次元平面 中の問題に最適化アプローチによる発生源同定を適用している。ま た建築分野においても、石田ら ${ }^{8}$ は は Computer fluid dynamics (CFD)に よる拡散解析を活用し、3 次元空間中の解析格子点各点からの仮想 的なトレーサーの単位放出と観測点での非定常濃度応答との関係を 調心、その応答係数行列を解くことで発生源位置および発生量の時 系列変化を推定寸る方法を提示している。しかし、潜在的な流れ場 および発生源の組み合わせは膨大な数に及ぶため、これら最適化手 法における事前の拡散解析の計算コス卜は自然と高いものとなる。

発生源同定の問題を時間逆転積分の問題として捉え、直接的に過 去の状況を解析する手法も検討されている。このような手法では、 污染物質が放出された後、環境中にある程度拡散してしまった状況 において、その時点の濃度分布を初期条件として、発生時点と考え られる時間まで移流拡散方程式を時間逆方向に積分することで、過 去の濃度分布を解析し、最も高濃度となる位置を発生源として同定 する。実際の解析は、移流や拡散の方向を反転させ、時間を正の方 向に積分することで実現されるが、拡散項の係数が負になることで

$\begin{array}{rlll}* & \text { 東京大学生産技術研究所 } & \text { 助教 · 博士 (工学) } \\ * * & \text { 東京大学生産技術研究所 } & \text { 教授 } \cdot \text { 博士 (工学) } \\ * * * & \text { 東京大学生産技術研究所 } & \text { 教授 } \cdot \text { 工博 }\end{array}$

$\begin{array}{ccc}* & \text { 東京大学生産技術研究所 } & \text { 助教 } \cdot \text { 博士 (工学) } \\ * * & \text { 東京大学生産技術研究所 } & \text { 教授 } \cdot \text { 博士 (工学) }\end{array}$

*** 東京大学生産技術研究所 教授.工博
Research Assoc., Institute of Industrial Science, The University of Tokyo, Ph.D.(Eng.)

Prof., Institute of Industrial Science, The University of Tokyo, Ph.D.(Eng.)

Prof., Institute of Industrial Science, The University of Tokyo, Dr.Eng. 
数値計算は極めて不安定となる ${ }^{9), 10) 。 ~}$

小林ら ${ }^{11)}$ は、空気余命の評価手法として、この CFDによる時間逆 転積分の手法を室内でのトレーサー拡散解析に適用した。しかし、 計算安定化のためとして拡散項の係数は正のまま解析が実施された。 Zhang, Chen ${ }^{2)}$ は、負の係数をもつ拡散項の 2 階微分を 4 階微分に変 更して安定性を確保する Quasi-reversibility 手法 ${ }^{12)}$ を採用し、2 次元 航空機キャビンと 3 次元オフィス空間での発生源同定を行っている。 Bady ら 13)あるいは安部, 加藤らの一連の研究 9), 10), 14), 15)では濃度あ るいは濃度フラックスヘフィルター操作を施すことで負拡散に起因 する数值不安定性を緩和し、境界層や建物周りの拡散場における発 生源同定を試みている。しかし、これらの負拡散への安定化手法が 加わることで、時間順方向での移流拡散方程式とは支配方程式が厳 密に一致しなくなるため、既往研究においても発生点近傍の濃度が 高くなるといった程度の結果しか得られていない。

このような状況の中、同様に移流方向を反転した流れ場での拡散 解析を利用した随伴法（Adjoint method）に基づく発生源同定手法が 開発されている。同手法では、環境污染物質の濃度場に対する随伴 濃度場と呼ばれる仮想的なスカラーを用意する。このスカラーは、 污染物質の観測点から単位発生強度で放出され、移流方向を反転し た流れ場でその濃度分布が解析される。ただし、拡散に関してはこ の反転流れ場での正の拡散として取り扱われるため、先述の移流拡 散方程式の時間逆転積分のような負拡散による計算不安定は生じな い。そして、定常状態においては、污染物質濃度と随伴濃度の輸送 現象の線形性から、移流拡散方程式を用いて解析的に(1)式のような スカラー場の双対関係（Duality）と呼ばれる関係が導かれる 16)。

$$
c\left(\mathbf{x}_{o}\right)=q_{s} c_{a}\left(\mathbf{x}_{s}\right)
$$

ここで、 $c\left(\mathbf{x}_{o}\right)$ は観測点 $\mathbf{x}_{o}$ における環境污染物質濃度、 $c_{a}\left(\mathbf{x}_{s}\right)$ は発生源 位置 $\mathbf{x}_{s}$ での随伴濃度、 $q_{s}$ は環境污染物質の発生強度である。

随伴濃度場を用いた発生源同定は、例えば、Neupauer, Wilson ${ }^{17}$ が 地下水污染の問題に、Pudykiewicz ${ }^{18)}$ が全球スケールでの放射線物質 のモニタリングに適用している。また、気象スケールでの大気拡散 の問題にも多く適用例があり 19-21)、Keats ら 16) は都市スケールでの 污染物質の発生源同定に用いている。

随伴濃度は、ある位置に污染物質発生源があった場合の観測点濃 度への影響度を示すものと解釈される。多数の発生源候補位置に対 して各々順方向の拡散解析を行う方法と比較し、随伴法は格段に小 さい計算コストで発生源と観測濃度との関係が調心゙られるため、発 生源同定において大変有用な手法である。しかし、随伴濃度は解析 的な観点から導入されるためその物理量としての意味が明確で無い。 そこで本研究ではまず、移流方向を反転した流れ場での粒子の拡 散挙動を考察する。そして、粒子位置の確率密度の観点から先の双 対関係を導出するとともに随伴濃度の新たな物理的解釈を与える。 また、一般の乱流拡散場において点源から放出された環境污染物質 に関して、この双対関係を利用した発生源の同定手法を提案する。 最後に、2 次元一様流れ場での環境污染物質の拡散問題を題材に、 本手法に基づく発生源同定の具体例を紹介寸る。

なお、本手法においては、流れ場や拡散場の解析、濃度計測など 必要とされる各手続きに全く誤差が混入しない理想的な状況におい ては、 $n$ 次元空間における発生源位置および発生強度の計 $n+1$ 個の 未知数に対して、それに等しい $n+1$ 個の観測点において環境污染
物質の濃度が観測されれば、原理的には厳密な意味で環境污染物質 の発生源位置および強度が同定される。

\section{2. 前提条件}

本研究が想定する流れおよび環境污染物質発生の条件を述べる。 まず、流れ場は非一様な一般乱流場を対象とするが、その統計的性 状は定常で、かつその空間的分布は極めて高い精度で解析可能であ るとする。また、環境污染物質は、流れに完全に追従し、かつ流れ 場には影響を与えないパッシブスカラーとしての性質を示し、化学 反応等の質的変化や沈着現象などによる消失も生じないものと仮定 する。そして、このような物質が、先の流れ場の中で未知の位置に 存在するひとつの点源から、時間的に一定の未知の発生強度で発生 し、その濃度を十分な数の観測点で計測したとする。

\section{3. 発生源同定の理論と手法}

\section{1. 粒子挙動の確率的表現と濃度の関係}

まず、流れに追従する粒子の一般流れ場における挙動を考察し、 拡散解析が与える濃度と粒子挙動の確率的表現との関係を考察する。

時刻 $t_{1}$ に位置 $\mathbf{x}_{1}$ にいた粒子が時刻 $t_{2}$ に位置 $\mathbf{x}_{2}$ にいる単位体積あ たりの確率密度関数を $p\left(\mathbf{x}_{2}, t_{2} \mid \mathbf{x}_{1}, t_{1}\right)$ と表現する。また、粒子の移動 を追跡する一定の検查空間を設定し、その体積を $V$ とする。

時刻 $t_{1}$ に $\mathbf{x}_{1}$ から放出された粒子が時刻 $t_{2}\left(t_{1} \leq t_{2}\right)$ にこの検査空間内 に存在する確率を $P_{V}\left(\mathbf{x}_{1}, t_{1}, t_{2}\right)$ とすれば、次の関係がある。

$$
\int_{V} p\left(\mathbf{x}_{2}, t_{2} \mid \mathbf{x}_{1}, t_{1}\right) \mathbf{d} \mathbf{x}_{2}=P_{V}\left(\mathbf{x}_{1}, t_{1}, t_{2}\right)
$$

しかし、定常状態を考えれば $P_{V}$ は $t_{1}, t_{2}$ に依らず、それらの差 $t_{3}=t_{2}$ $-t_{1}$ のみの関数となり、(2)式は(3)式のように書き換えられる。

$$
\int_{V} p\left(\mathbf{x}_{2}, t_{2} \mid \mathbf{x}_{1}, t_{2}-t_{3}\right) \mathbf{d} \mathbf{x}_{2}=P_{V}\left(\mathbf{x}_{1}, t_{3}\right)
$$

$P_{V}\left(\mathbf{x}_{1}, t_{3}\right)$ は、 $t_{3}=0$ で $1 、 t_{3} \rightarrow \infty$ で 0 となるような関数であり、 $\mathbf{x}_{1}$ か ら放出された粒子がその後この検査空間内に留まっている平均的時 間を $T$ とすれば(4)式を満たす。

$$
\int_{0}^{\infty} P_{V}\left(\mathbf{x}_{1}, t_{3}\right) d t_{3}=T
$$

定常的に単位時間あたり $q$ の割合で $\mathbf{x}_{1}$ から粒子を放出し続ける。 この場合、検查空間内に平均的に見出す粒子の数は、(5)式で与えら れる。ただし、Cは検査空間内の平均粒子濃度である。

$$
\begin{aligned}
& \int_{0}^{\infty} q \int_{V} p\left(\mathbf{x}_{2}, t_{2} \mid \mathbf{x}_{1}, t_{2}-t_{3}\right) \mathbf{d} \mathbf{x}_{2} d t_{3} \\
& \quad=q \int_{0}^{\infty} P_{V}\left(\mathbf{x}_{1}, t_{3}\right) d t_{3}=q T=C V
\end{aligned}
$$

またここで、 $\mathbf{x}_{1}$ から放出された粒子が $\mathbf{x}_{2}$ 周りの微小体積内に滞在 する時間の単位体積あたりの期待值を $s\left(\mathbf{x}_{2} \mid \mathbf{x}_{1}\right)$ と表記すれば、ひと つの粒子挙動の確率密度と次の関係がある。

$$
s\left(\mathbf{x}_{2} \mid \mathbf{x}_{1}\right)=\int_{0}^{\infty} p\left(\mathbf{x}_{2}, t_{2} \mid \mathbf{x}_{1}, t_{2}-t_{3}\right) d t_{3}
$$

これを用いれば、 $s\left(\mathbf{x}_{2} \mid \mathbf{x}_{1}\right) \mathbf{d} \mathbf{x}_{2}$ によって粒子が $\mathbf{x}_{2}$ 周りの微小体積 $\mathbf{d x}_{2}$ の中に滞在する時間の期待值が表される。

積分順序の可換性に注意すれば、(5)式より、

$$
\int_{V} \int_{0}^{\infty} p\left(\mathbf{x}_{2}, t_{2} \mid \mathbf{x}_{1}, t_{2}-t_{3}\right) d t_{3} \mathbf{d} \mathbf{x}_{2}=\int_{V} s\left(\mathbf{x}_{2} \mid \mathbf{x}_{1}\right) \mathbf{d} \mathbf{x}_{2}=T
$$


これもまた $\mathbf{x}_{1}$ から放出されたひとつの粒子の検査空間内に留まる 平均的時間が $T$ であるという設定と対応している。

検查空間内の平均濃度は $s\left(\mathbf{x}_{2} \mid \mathbf{x}_{1}\right)$ を用いて(5)式、(7)式から次のよ うに書ける。

$$
C=\frac{q}{V} \int_{V} S\left(\mathbf{x}_{2} \mid \mathbf{x}_{1}\right) \mathbf{d} \mathbf{x}_{2}
$$

また、Cは定常状態における各点の平均濃度 $c\left(\mathbf{x}_{2}\right)$ を用いて次のよう にも表現できる。

$$
C=\frac{1}{V} \int_{V} c\left(\mathbf{x}_{2}\right) \mathbf{d} \mathbf{x}_{2}
$$

(8)式と(9)式を見比べれば、(10)式の関係が得られる。

$$
c\left(\mathbf{x}_{2}\right)=q s\left(\mathbf{x}_{2} \mid \mathbf{x}_{1}\right)
$$

つまり、定常状態におけるある位置の濃度とは、粒子の発生強度 と、その粒子が対象位置周辺の微小空間に滞在する時間の単位体積 あたりの期待值とを掛け合わせたものに等しい。したがって、ある 発生強度 $q$ における濃度分布 $c\left(\mathbf{x}_{2}\right)$ が得られれば、(10)式から $s\left(\mathbf{x}_{2} \mid \mathbf{x}_{1}\right)$ を評価できる。

\section{2. 反転流れ場における粒子挙動}

検査空間内において $\widetilde{\mathbf{u}}(\mathbf{x}, t)=\mathbf{U}(\mathbf{x})+\mathbf{u}(\mathbf{x}, t)(\mathbf{U}$ : 平均速度ベクトル; $\mathbf{u}$ : 乱れ速度ベクトル) の流れ場が存在し、その中で污染物質の拡散 が生じたとする。その際、各位置の速度と時間方向を反転した流れ 場 $\widetilde{\mathbf{u}}^{*}\left(\mathbf{x}, t^{*}\right)=-\widetilde{\mathbf{u}}(\mathbf{x}, t)\left(\mathbf{U}^{*}(\mathbf{x})=-\mathbf{U}(\mathbf{x}), \mathbf{u}^{*}\left(\mathbf{x}, t^{*}\right)=-\mathbf{u}(\mathbf{x}, t), t^{*}=-t\right)$ を 人為的に作成し、これを本研究では反転流れ場 (Reversed flow field) と呼ぶ。また、元の流れ場 $\widetilde{⿱}$ を順流れ場（Forward flow field）と呼ぶ。 反転流れ場での変数であることを明記する場合には変数の右肩に* （アスタリスク）を付す。

定常な乱流拡散場においては、粒子は平均的にその場の平均流に 従って移動するとともに、それと独立して、乱流拡散あるは分子拡 散などによって、ランダムな方向に、統計的にはその位置の拡散能 力に応じた距離を移動する。例えば、順流れ場においてひとつの粒 子が Fig. 1(1)に示すような経路に沿って、時刻 $t$ から $t+\Delta t$ の間に $\mathbf{x}_{1}$ から $\mathbf{x}_{2}$ まで移動したとする。ここで、これに対応する反転流れ場を 用意し、 $\mathbf{x}_{2}$ からひとつの粒子が放出されたとすれば、Fig. 1(2)のよう

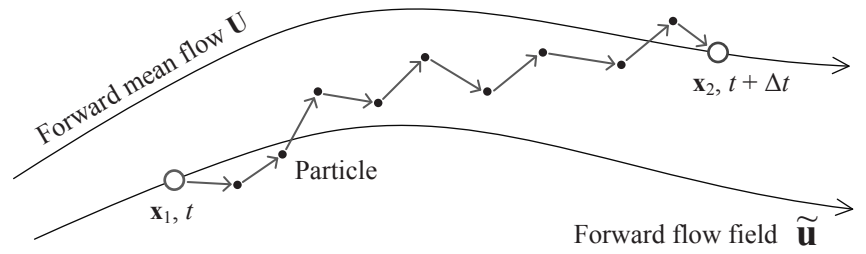

(1) A particle path in the forward flow field

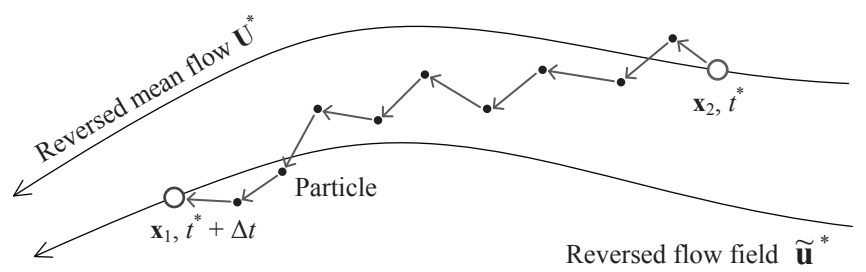

(2) A particle path in the reversed flow field

Fig. 1 Conceptual paths of the particle behavior in the forward flow field and its corresponding reversed flow field.
に時刻 $t^{*}$ から $t^{*}+\Delta t$ の間に、ちょうど Fig. 1(1)の経路を逆にたどる 形で $\mathbf{x}_{1}$ に到達する経路があり得る。

位置 $\mathbf{x} 、$ 時刻 $t$ における瞬時速度 $\widetilde{\mathbf{u}}(\mathbf{x}, t)$ を用いて、流れ場に対して パッシブで完全に追随する粒子の位置の時間変化は(11)式のように 書ける。

$$
\frac{\partial \mathbf{x}}{\partial t}=\widetilde{\mathbf{u}}(\mathbf{x}, t)
$$

順流れ場における粒子の $\mathbf{x}_{1}$ から $\mathbf{x}_{2}$ までの移動を記述すれば、

$$
\mathbf{x}_{2}=\mathbf{x}_{1}+\int_{t\left(\mathbf{x}_{1}\right)}^{t+\Delta t\left(\mathbf{x}_{2}\right)} \widetilde{\mathbf{u}}\left(\mathbf{x}\left(t^{\prime}\right), t^{\prime}\right) d t^{\prime}
$$

のように書けるが、(12)式はまた次のように変形できる。

$$
\begin{aligned}
\mathbf{x}_{1} & =\mathbf{x}_{2}-\int_{t\left(\mathbf{x}_{1}\right)}^{t+\Delta t\left(\mathbf{x}_{2}\right)} \widetilde{\mathbf{u}}\left(\mathbf{x}\left(t^{\prime}\right), t^{\prime}\right) d t^{\prime} \\
& =\mathbf{x}_{2}+\int_{t+\Delta t\left(\mathbf{x}_{2}\right)}^{t\left(\mathbf{x}_{1}\right)} \widetilde{\mathbf{u}}\left(\mathbf{x}\left(t^{\prime}\right), t^{\prime}\right) d t^{\prime} \\
& =\mathbf{x}_{2}-\int_{t^{*}\left(\mathbf{x}_{2}\right)}^{t^{*}+\Delta t\left(\mathbf{x}_{1}\right)} \widetilde{\mathbf{u}}\left(\mathbf{x}\left(t^{\prime \prime}\right), t^{\prime \prime}\right) d t^{\prime \prime} \quad\left(d t^{\prime \prime}=-d t^{\prime}\right) \\
& =\mathbf{x}_{2}+\int_{t^{*}\left(\mathbf{x}_{2}\right)}^{t^{*}+\Delta t\left(\mathbf{x}_{1}\right)} \widetilde{\mathbf{u}}^{*}\left(\mathbf{x}\left(t^{\prime \prime}\right), t^{\prime \prime}\right) d t^{\prime \prime}
\end{aligned}
$$

ここで、上式(A)では、(12)式の右辺の積分項を移動したが、時間積 分に対応寸る空間経路は $\mathbf{x}_{1} \rightarrow \mathbf{x}_{2}$ のままである。(B)では、順流れ場 で時間の積分方向を逆にし、対応する空間経路を $\mathbf{x}_{2} \rightarrow \mathbf{x}_{1}$ に変化さ せた。(C)では、順流れ場で時間の進行方向を反転させ、(D)において 順流れ場を反転流れ場で置き換えた。

(12)式と(13)式より、順流れ場と反転流れ場での $\mathbf{x}_{1}$ と $\mathbf{x}_{2}$ の間の移 動には対称性が存在する。また、各位置での順流れ場および反転流 れ場における乱流変動べクトルの確率密度関数 $p(\mathbf{u}(\mathbf{x})), p\left(\mathbf{u}^{*}(\mathbf{x})\right)$ には、 $p(\mathbf{u}(\mathbf{x}))=p\left(-\mathbf{u}^{*}(\mathbf{x})\right)$ の関係がある。つまり、平均流の対称性と併せ、 順流れ場と反転流れ場の同位置では、粒子は同確率で正反対の方向 に進む。よって、粒子が反転流れ場において Fig. 1(2)のような経路 をとる確率は、順流れ場において Fig. 1(1)のような経路をとる確率 と同じである。

順流れ場において $\mathbf{x}_{1}$ から出発した粒子は、Fig. 1(1)に示した以外 にも無数の粒子経路をとって移動する可能性があり、あるものは $\mathbf{x}_{2}$ を通過し、他方で当然 $\mathbf{x}_{2}$ を通過しないものもある。しかし、順流れ 場において $\mathbf{x}_{1}$ から放たれた粒子が $\mathbf{x}_{2}$ を通過するような経路をとっ たと寸るならば、必ずそれに対応して $\mathbf{x}_{2}$ から放たれた粒子が $\mathbf{x}_{1}$ を 通過する経路が時空間的に反転流れ場においても発生しており、順 流れ場と反転流れ場において $\mathbf{x}_{1}$ と $\mathbf{x}_{2}$ との間を粒子が移動する各経 路の発生確率は等しい值をとる。

以上の議論より、順流れ場において時刻 $t$ に $\mathbf{x}_{1}$ にいた粒子が時刻 $t+\Delta t$ に $\mathbf{x}_{2}$ にいる確率の密度関数 $p\left(\mathbf{x}_{2}, t+\Delta t \mid \mathbf{x}_{1}, t\right)$ と、反転流れ場に おいて時刻 $t^{*}$ に $\mathbf{x}_{2}$ にいた粒子が時刻 $t^{*}+\Delta t$ に $\mathbf{x}_{1}$ にいる確率の密度 関数 $p^{*}\left(\mathbf{x}_{1}, t^{*}+\Delta t \mid \mathbf{x}_{2}, t^{*}\right)$ は互いに等しい ((14)式)。

$$
p\left(\mathbf{x}_{2}, t+\Delta t \mid \mathbf{x}_{1}, t\right)=p^{*}\left(\mathbf{x}_{1}, t^{*}+\Delta t \mid \mathbf{x}_{2}, t^{*}\right)
$$

(14)式と(6)式から、定常状態の順流れ場において $\mathbf{x}_{1}$ から放出され た粒子が $\mathbf{x}_{2}$ に滞在する時間の期待值 $s\left(\mathbf{x}_{2} \mid \mathbf{x}_{1}\right)$ と、反転流れ場におい て $\mathbf{x}_{2}$ から放出された粒子が $\mathbf{x}_{1}$ に滞在する時間の期待值 $s^{*}\left(\mathbf{x}_{1} \mid \mathbf{x}_{2}\right)$ との 間には(15)式の関係が導かれる。

$$
s\left(\mathbf{x}_{2} \mid \mathbf{x}_{1}\right)=s^{*}\left(\mathbf{x}_{1} \mid \mathbf{x}_{2}\right)
$$

つまり、 $s\left(\mathbf{x}_{2} \mid \mathbf{x}_{1}\right)$ を知りたければ、反転流れ場を用意し、粒子を観測 
した $\mathbf{x}_{2}$ から仮想的なトレーサーを放出することで、その濃度分布と (10)式の関係から $s^{*}\left(\mathbf{x}_{1} \mid \mathbf{x}_{2}\right)$ を調べれば良い。

\section{3. スカラー場の双対関係}

位置 $\mathbf{x}_{s}$ から発生強度 $q_{s}$ で環境污染物質が放出され、観測点 $\mathbf{x}_{o}$ に て同物質の濃度 $c\left(\mathbf{x}_{o}\right)$ が計測されたとする。また、対応する反転流れ 場において、観測点 $\mathbf{x}_{o}$ から発生強度 $q^{*}$ で仮想的なトレーサーを放出 し、発生源位置 $\mathbf{x}_{s}$ において同トレーサーの濃度は $c^{*}\left(\mathbf{x}_{s}\right)$ であったと する。いま、仮想的なトレーサーを単位強度で放出した場合 $\left(q^{*}=1\right)$ には、(10)式より $c^{*}\left(\mathbf{x}_{s}\right)=s^{*}\left(\mathbf{x}_{s} \mid \mathbf{x}_{o}\right)$ である。したがって、(10)式, (15)式 を用いれば、これらの量の間には次のような関係が存在する。

$$
c\left(\mathbf{x}_{o}\right)=q_{s} s^{*}\left(\mathbf{x}_{s} \mid \mathbf{x}_{o}\right)=q_{s} c^{*}\left(\mathbf{x}_{s}\right)
$$

これは、随伴法におけるスカラー場の双対関係（(1)式）に他ならな い ${ }^{16)}$ 。また、 $c_{a}\left(\mathbf{x}_{s}\right)=s^{*}\left(\mathbf{x}_{s} \mid \mathbf{x}_{o}\right)$ であるから随伴濃度とは、反転流れ場 において観測点から放出された仮想粒子が污染物質発生点周囲の微 小体積に滞在する時間の単位体積あたりの期待値である。

\section{4. 発生源の同定方法}

対象とする環境污染物質の点源が未知の位置 $\mathbf{x}_{s}$ に存在し、順流れ 場 $\widetilde{\mathbf{u}}$ の中で未知の発生強度 $q_{s}$ でその物質を定常的に発生していると する。その環境污染物質の濃度を複数の観測点 $\mathbf{x}_{o, i}(i=1,2, \ldots, N ; N$ は観測点数)で計測し、それぞれ観測した濃度が $c_{o, i}$ だったとする。

そこで反転流れ場 $\widetilde{\mathbf{u}}^{*}=-\widetilde{\mathbf{u}}$ を用意し、その中で観測点 $\mathbf{x}_{o, i}$ それぞれ の位置に仮想的なトレーサーの発生源を設定し、それぞれ $q_{i}^{*}$ の発生 強度で定常的にトレーサーを発生する。 $\mathbf{x}_{o, i}$ に設置したトレーサー発 生源により $\mathbf{x}$ に生じる濃度を $c_{i}^{*}(\mathbf{x})$ とすれば、(10)式の関係から次式 のように $s^{*}\left(\mathbf{x} \mid \mathbf{x}_{o, i}\right)$ が求まる。

$$
s^{*}\left(\mathbf{x} \mid \mathbf{x}_{o, i}\right)=\frac{c_{i}^{*}(\mathbf{x})}{q_{i}^{*}}
$$

$s^{*}\left(\mathbf{x} \mid \mathbf{x}_{o, i}\right)$ を用いれば、次式のように環境污染物質の発生源が $\mathbf{x}$ に あると仮定した場合の発生強度の推定值 $q_{s, i}(\mathbf{x})$ が求まる。

$$
q_{s, i}(\mathbf{x})=\frac{c_{o, i}}{s\left(\mathbf{x}_{o, i} \mid \mathbf{x}\right)}=\frac{c_{o, i}}{s^{*}\left(\mathbf{x} \mid \mathbf{x}_{o, i}\right)}
$$

この手続きを $N$ 個の観測点それぞれに対して実施すれば、発生源 の候補となる位置 $\mathbf{x}$ に対して $N$ 個の発生強度の推定值 $q_{s, i}$ が算出で きる。しかし、物理的に発生強度は唯一の值でなければならない。 したがって、次式を満たす $\mathbf{x}_{s}$ が環境污染物質の発生源位置と定まり、 同時に $q_{s, i}\left(\mathbf{x}_{s}\right)$ が環境污染物質の発生強度である。

$$
q_{s, 1}\left(\mathbf{x}_{s}\right)=q_{s, 2}\left(\mathbf{x}_{s}\right)=\cdots=q_{s, N}\left(\mathbf{x}_{s}\right)
$$

ただし、 $q_{s, i}(\mathbf{x})$ の計算において $(18)$ 式を用いるが、 $s^{*}\left(\mathbf{x} \mid \mathbf{x}_{o, i}\right)$ は極め て小さい值をもつ可能性があり、 $s^{*}\left(\mathbf{x} \mid \mathbf{x}_{o, i}\right)$ が分母にあると $q_{s, i}(\mathbf{x})$ の計 算が数值的に不安定となりうる。そこで、実際の計算においては、 (18)式あるいは(19)式の各項の逆数をとり、(20)式を満たす $\mathbf{x}_{s}$ を求め るのがよい。

$$
\begin{aligned}
& \frac{1}{q_{s, 1}\left(\mathbf{x}_{s}\right)}=\frac{1}{q_{s, 2}\left(\mathbf{x}_{s}\right)}=\cdots=\frac{1}{q_{s, N}\left(\mathbf{x}_{s}\right)} \\
& \quad \text { or } \frac{s^{*}\left(\mathbf{x}_{s} \mid \mathbf{x}_{o, 1}\right)}{c_{o, 1}}=\frac{s^{*}\left(\mathbf{x}_{s} \mid \mathbf{x}_{o, 2}\right)}{c_{o, 2}}=\cdots=\frac{s^{*}\left(\mathbf{x}_{s} \mid \mathbf{x}_{o, N}\right)}{c_{o, N}}
\end{aligned}
$$

発生源同定における未知数は発生源の位置ベクトル $\mathbf{x}_{s}$ の各成分と 発生強度 $q_{s}$ であり、 $n$ 次元空間での問題では未知数の数は $n+1$ で
ある。したがって、濃度計測や拡散解析などここまでの手続きにお いて誤差が全く混入しない理想的な状況においては、最低限 $n+1$ 個 の観測点で濃度が計測できれば発生源の同定が可能となる。

\section{4. 発生源同定のアルゴリズム}

ここまでの議論を踏まえ、本研究が提案する発生源同定のアルゴ リズムを以下にまとめる。

(1) $N$ 個の観測点において対象とする環境污染物質の濃度 $c_{o, i}(i=1$, $2, \ldots, N)$ を計測する。

(2) 検查空間中の順流れ場 $\widetilde{\mathbf{u}}$ 解析的または数值的に得る。

(3) 反転流れ場 $\widetilde{\mathbf{u}}^{*}=-\widetilde{\mathbf{u}}$ を作成する。ただし、平均場を解析するモデ ルにおいては、平均流れ場を反転すれば良い $\left(\mathbf{U}^{*}=-\mathbf{U}\right)$ 。

(4) 反転流れ場においてひとつの観測点 $\mathbf{x}_{o, i}$ から仮想的なトレーサ 一を発生強度 $q_{i}^{*}$ で放出し、解析的または数值的にその濃度分布 $c_{i}^{*}(\mathbf{x})$ を得る。

(5) $c_{i}^{*}(\mathbf{x})$ から $s^{*}\left(\mathbf{x} \mid \mathbf{x}_{o, i}\right)=c_{i}^{*}(\mathbf{x}) / q_{i}^{*}$ を計算し、さらに $1 / q_{s, i}(\mathbf{x})=s^{*}(\mathbf{x} \mid$ $\left.\mathbf{x}_{o, i}\right) / c_{o, i}$ の分布を求める。

(6) (4)と(5)の手続きを $N$ 個の観測点すべてに関して実施する。

(7) $1 / q_{s, 1}\left(\mathbf{x}_{s}\right)=1 / q_{s, 2}\left(\mathbf{x}_{s}\right)=\ldots=1 / q_{s, N}\left(\mathbf{x}_{s}\right)$ となる $\mathbf{x}_{s}$ を求める。

(8) $\mathbf{x}_{s}$ が環境污染物質の発生源位置であり、 $q_{s, i}\left(\mathbf{x}_{s}\right)$ が環境污染物質の 発生強度 $q_{s}$ である。

\section{5. 発生源同定の例（2 次元一様流れ場での環境污染物質拡散）}

本手法を用いた発生源同定の具体例を示す。本手法は、原理的に は 3 次元空間における一般乱流場での拡散問題においても有効であ る。しかし、問題を簡単にし、かつ数值解析における誤差の混入な どを避けるため、本論文では 2 次元一様流れ場での環境污染物質の 拡散という単純な状況を設定することにした。

\section{1. 問題設定}

2 次元空間 $(x-y$ 平面 $)$ 内での拡散現象を考え、検查空間中におい て一様に $\mathbf{U}=(u, v)=(5,0)$ の平均流れ場が存在する。環境污染物質の 拡散係数 $\gamma$ は検查空間中で一様に $\gamma=4$ とする。実際に発生源同定が 必要とされる状況では未知のものであるが、この例題においては、 環境污染物質の発生源が $\mathbf{x}_{s}=\left(x_{s}, y_{s}\right)=(3,2)$ にあり、発生強度は $q_{s}=$ 10 であるとし、これらが同定対象のパラメータとなる。対象物質の 観測点は 3 点（Obs1, Obs2, Obs3）あり、それぞれの位置は $\mathbf{x}_{o, 1}=(12$, 6), $\mathbf{x}_{o, 2}=(21,3), \mathbf{x}_{o, 3}=(15,-2)$ であるとする。ただし、ここに挙げた以

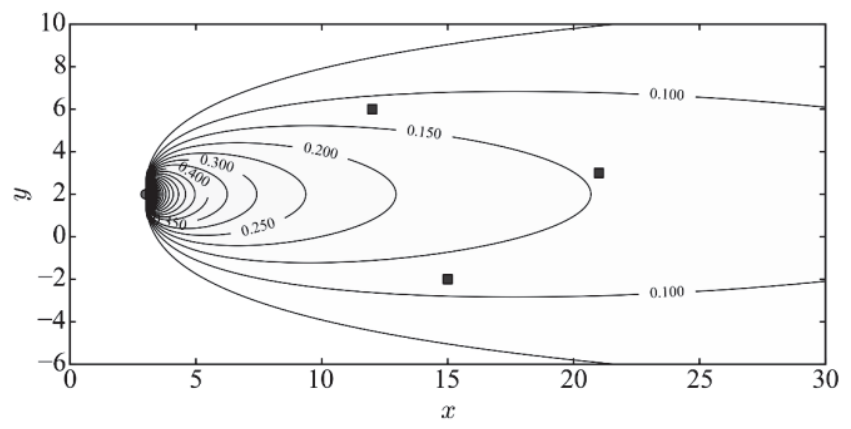

Fig. 2 Concentration distribution of the environmental pollutant in a two-dimensional uniform flow field. Circle shows the position of the pollutant source; Square shows positions of three observation sites. 
上の数值は、問題の設定上便宜的に与えたものであり、特に物理的 根拠があるものではない。

\section{2. 順流れ場での濃度分布}

前節に記したような単純な拡散場の状況においては、順流れ場で の濃度 $c(\mathbf{x})\left(x>x_{s}\right)$ はガウス・プルームモデル 3)に従って(21)式のよ うに分布する。ただし、ここで $\sigma$ は拡散幅である。

$$
\begin{gathered}
c(\mathbf{x})=\frac{q_{s}}{u \sqrt{2 \pi \sigma^{2}}} \exp \left[-\frac{\left(y-y_{s}\right)^{2}}{2 \sigma^{2}}\right], \\
\sigma=(2 \gamma t)^{1 / 2}=\left[2 \gamma \frac{x-x_{s}}{u}\right]^{1 / 2}
\end{gathered}
$$

したがって、観測点 $\mathbf{x}_{o, i}=\left(x_{o, i}, y_{o, i}\right)$ では濃度は(22)式のようになる。

$$
c_{o, i}=c\left(\mathbf{x}_{o, i}\right)=\frac{q_{s}}{\sqrt{4 \pi \gamma u\left(x_{o, i}-x_{s}\right)}} \exp \left[-\frac{u\left(y_{o, i}-y_{s}\right)^{2}}{4 \gamma\left(x_{o, i}-x_{s}\right)}\right]
$$

具体的な濃度の值は Obs1, Obs2, Obs3 で順に $c_{o, 1}=0.121, c_{o, 2}=0.146$, $c_{o, 3}=0.120$ のように計測される。Fig. 2 に環境污染物質の濃度分布を 示す。ただし、発生源同定を行うにあたっては当然このような濃度 分布の全体像は把握できておらず、流れ場 $\mathbf{U}$ と観測濃度 $c_{o, i}(i=1,2$, 3)のみの情報しか与えられない。

\section{3. 反転流れ場でのトレーサー拡散}

反転流れ場 $\mathbf{U}^{*}=(-u, 0)$ において観測点 $\mathbf{x}_{o, i}$ から仮想的なトレーサ 一を発生強度 $q_{i}^{*}$ で放出する。この場合もプルームモデルによってト レーサーの濃度 $c_{i}^{*}(\mathbf{x})\left(x<x_{o, i}\right)$ の分布は次式より予測される。

$$
c_{i}^{*}(\mathbf{x})=\frac{q_{i}^{*}}{\sqrt{4 \pi \gamma(-u)\left(x-x_{o, i}\right)}} \exp \left[\frac{u\left(y-y_{o, i}\right)^{2}}{4 \gamma\left(x-x_{o, i}\right)}\right]
$$

これを用いて $s^{*}\left(\mathbf{x} \mid \mathbf{x}_{o, i}\right)=c_{i}^{*}(\mathbf{x}) / q_{i}^{*}$ を求めると(24)式のようになり、 その分布を図示寸ると Fig. 3 のようになる。

$$
s^{*}\left(\mathbf{x} \mid \mathbf{x}_{o, i}\right)=\frac{1}{\sqrt{4 \pi \gamma(-u)\left(x-x_{o, i}\right)}} \exp \left[\frac{u\left(y-y_{o, i}\right)^{2}}{4 \gamma\left(x-x_{o, i}\right)}\right]
$$

ところで(24)式は、次式のようにも変形できる。

$$
s^{*}\left(\mathbf{x} \mid \mathbf{x}_{o, i}\right)=\frac{1}{\sqrt{4 \pi \gamma u\left(x_{o, i}-x\right)}} \exp \left[-\frac{u\left(y_{o, i}-y\right)^{2}}{4 \gamma\left(x_{o, i}-x\right)}\right]
$$

(25)式の右辺は、順流れ場において $\mathbf{x}$ から粒子を放出した場合の $\mathbf{x}_{o, i}$ における滞在時間の期待值 $s\left(\mathbf{x}_{o, i} \mid \mathbf{x}\right)$ ともみなせる。つまり、プルーム モデルの観点からも(15)式の関係の存在が示された。

\section{4. 発生源の同定}

(20)式の関係を満たす $\mathbf{x}_{s}$ を探查するため、観測点の組み合わせか ら $1 / q_{s, i}(\mathbf{x})-1 / q_{s, j}(\mathbf{x})=s^{*}\left(\mathbf{x} \mid \mathbf{x}_{o, i}\right) / c_{o, i}-s^{*}\left(\mathbf{x} \mid \mathbf{x}_{o, j}\right) / c_{o, j}(i, j=1,2,3 ; i \neq j)$ の分 布を求め Fig. 4 に示寸。Fig. 4 の各図において正值と負值領域の境 界の実線、つまり $1 / q_{s, i}(\mathbf{x})-1 / q_{s, j}(\mathbf{x})=0$ となる曲線の上の各点が、選 択された $2 つ の$ 観測点からのトレーサー拡散解析に基づいた環境污 染物質発生源位置の候補となる。

そして、Fig. 5 において Fig. 4(1)と Fig. 4(2)を重ねて図示すれば、 曲線 $1 / q_{s, 1}(\mathbf{x})-1 / q_{s, 2}(\mathbf{x})=0$ と $1 / q_{s, 2}(\mathbf{x})-1 / q_{s, 3}(\mathbf{x})=0$ の交点がひとつ定 まる。この交点が同定された環境污染物質の発生源であり、Fig. 2 の 設定した発生源位置と一致している。発生強度は(18)式の関係から

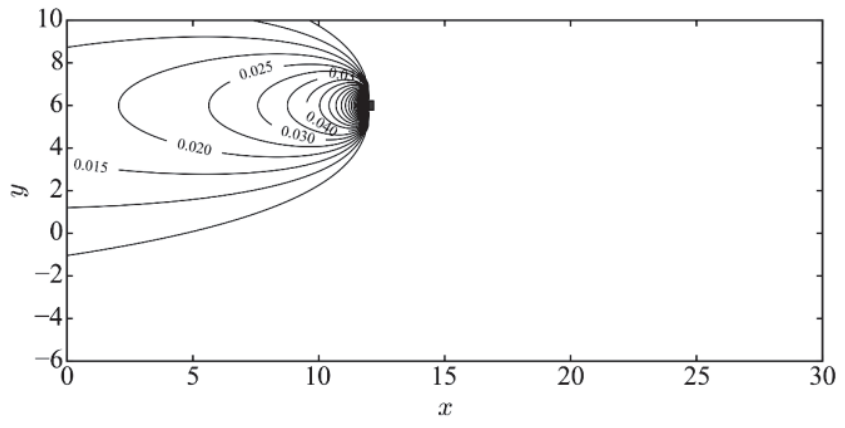

(1) Tracer release from Obs1 and $s^{*}\left(\mathbf{x} \mid \mathbf{x}_{o, 1}\right)$

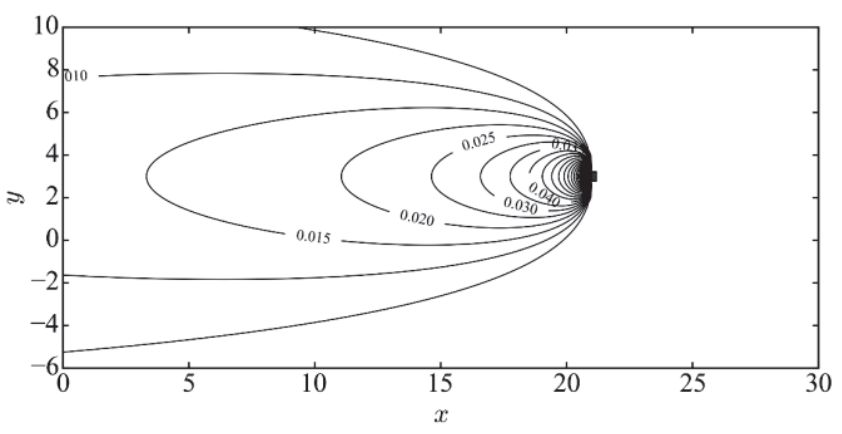

(2) Tracer release from Obs2 and $s^{*}\left(\mathbf{x} \mid \mathbf{x}_{o, 2}\right)$

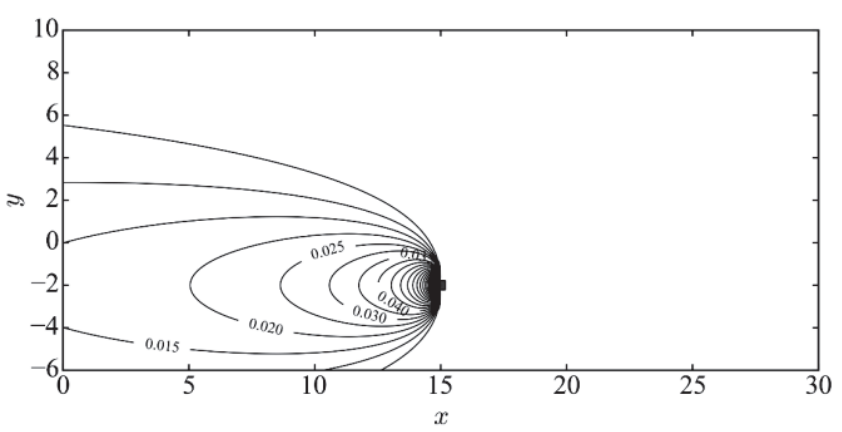

(3) Tracer release from Obs3 and $s^{*}\left(\mathbf{x} \mid \mathbf{x}_{o, 3}\right)$

Fig. 3 Distributions of the expected staying time per unit volume of the tracer particles in the reversed flow field. Square shows positions of three observation sites.

求まることが明らかなのでここでは割愛する。以上より、対象とす る環境污染物質の発生源同定が完了する。

\section{6. まとめと今後の課題}

一般の乱流拡散場における点源から定常的に発生する環境污染物 質の拡散問題に関して、反転流れ場でのトレーサー粒子挙動を確率 的な観点から考察し、その拡散性状に基づく発生源同定手法を提案 した。ここで反転流れ場とは、環境污染物質が拡散した流れ場（順 流れ場）に対して、時間の進行方向と各点の速度ベクトルを反転し た仮想的流れ場である。

乱流拡散場の統計的定常状態においては、物質のある位置の濃度 は、物質の発生強度とその物質粒子が対象位置に滞在する時間の期 待値と関係づけられる。その滞在時間の期待值はまた、順流れ場と 反転流れ場とで粒子の放出源と観測点の関係を入れ替えれば互いに 等しい值を示す。その結果、反転流れ場において、環境污染物質の 観測点から仮想的なトレーサーを放出しその拡散解析を実施すれば、 


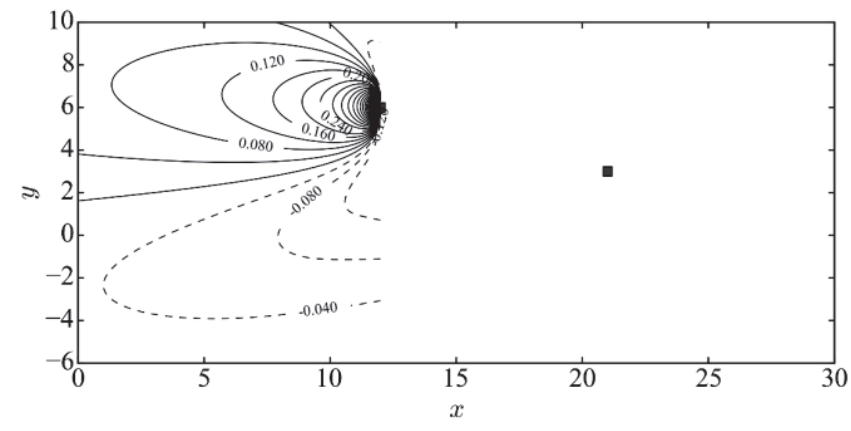

(1) Obs1 and Obs2, $1 / q_{s, 1}(\mathbf{x})-1 / q_{s, 2}(\mathbf{x})$

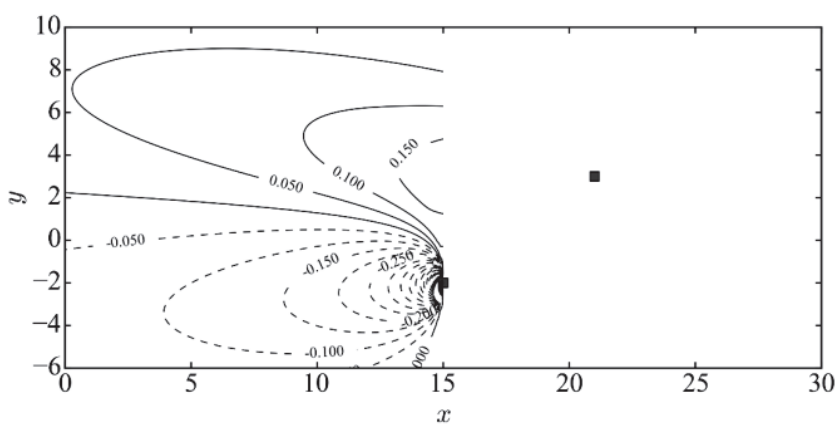

(2) Obs2 and Obs3, $1 / q_{s, 2}(\mathbf{x})-1 / q_{s, 3}(\mathbf{x})$

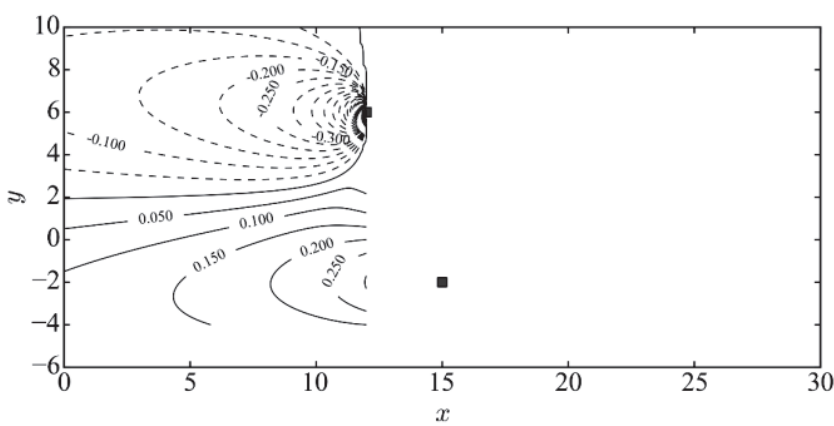

(3) Obs3 and Obs1, 1/ $q_{s, 3}(\mathbf{x})-1 / q_{s, 1}(\mathbf{x})$

Fig. 4 Distributions of the difference between inverse estimated source strengths obtained from the tracer dispersion analysis release from two different observation sites.

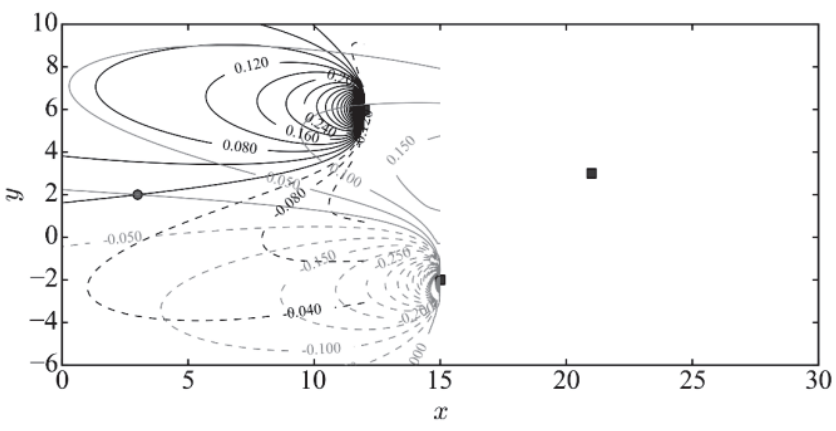

Fig. 5 Overlapped distributions of the difference between inverse estimated source strengths obtained from the tracer dispersion analysis release from two different observation sites. Distributions in Fig. 4(1) and (2) are replotted in the same frame. Black line shows $1 / q_{s, 1}(\mathbf{x})-1 / q_{s, 2}(\mathbf{x})$; Gray line shows $1 / q_{s, 2}(\mathbf{x})-1 / q_{s, 3}(\mathbf{x})$; Circle is the intersection point of $1 / q_{s, 1}(\mathbf{x})-1 / q_{s, 2}(\mathbf{x})=0$ and $1 / q_{s, 2}(\mathbf{x})-1 / q_{s, 3}(\mathbf{x})=0$, which means the estimated source point.
そのトレーサーの濃度分布と污染物質の観測濃度を用いて、環境污 染物質の発生源位置をある位置に仮定した場合の発生強度の推定值 が得られる。これは、随伴法におけるスカラー場の双対関係と等し く、随伴濃度とは、反転流れ場において観測点から放出されたトレ 一サー粒子が污染物質発生源位置周囲の微小体積に滞在する時間の 単位体積あたりの期待值であることが考察された。

複数の観測点が存在すれば、それぞれの観測点をトレーサー放出 源とした解析を実施し、各発生源位置候補に対して観測点数に等し い数だけ発生強度の推定值が得られる。しかし、物理的に発生強度 は唯一の值をとる必要があるため、この条件から発生源位置の候補 が絞られる。同定すべきパラメータは $n$ 次元空間において空間座標 と発生強度の $n+1$ 個存在するため、最低限 $n+1$ 個の観測点があれ ば発生源位置をひとつの点に決定できる。

本手法は、厳密には無限小の大きさをもつひとつの点源からの污 染物質の放出において有効である。発生源が有限の大きさをもつ場 合や発生源が複数点存在する場合には、発生源の重心のようなもの が同定結果として得られてしまうと予想される。特に、複数の発生 源の影響を受ける観測点の濃度からは個々の発生源の影響を分離で きない。複数発生源の問題への拡張は今後の課題としたい。

本手法はまた、検查空間中の流れ場が完全に解析的あるいは数值 的に再現可能であり、かつ濃度計測や拡散解析においても誤差が全 く混入しない状況を前提とする。しかし、実問題においてはこのよ うな理想的状況は発生しえず、逆問題としての発生源同定の性質か ら、これらの誤差に対して解が鋭敏に反応し不安定となる可能性が ある。また、使用寸る観測点の組み合わせによって、異なる複数の 発生点候補が生じてしまう可能性もある。しかし、多数の観測点が あれば真の発生点の周辺に発生源候補点が集中寸ることが期待でき る。あるいは、複数の候補点においてもそれぞれの発生点としての 信頼度は異なるものと考えられる。これらの観点から、より確から しい発生源候補点を探索し、誤差の混入に対してロバストな解を与 える追加的手法を本論文に続く研究で検討する予定である。

以上のような課題が残されているが、本論文では本手法の基本原 理を説明するとともに、2 次元一様流れ場で物質やトレーサーの濃 度分布も解析的に与えられるような理想的状況における適用事例を 示した。

\section{謝辞}

本研究の一部は、JSPS 科研費 26709041 (研究代表者: 菊本英紀) の助成を受け行われた。また、本手法の理論的考察に関して、東京 大学生産技術研究所の長谷川洋介准教授から貴重なご意見を頂いた。 記してここに謝意を表する。

$\begin{array}{ll}\text { 変数表記一覧 } & \\ * & \text { 反転流れ場での変数であることを示す } \\ c & \text { 濃度 } \\ c_{a} & \text { 随伴濃度 } \\ c_{i}^{*} & i \text { 番目の観測点から放出したトレーサーの濃度 } \\ c_{o, i} & i \text { 番目の観測点で計測された環境污染物質濃度 } \\ C & \text { 検査体積中の粒子の平均濃度 } \\ i, j & \text { 整数変数 } \\ n & \text { 空間の次元数 } \\ N & \text { 観測点数 }\end{array}$




$\begin{array}{ll}\text { Obs } 1 / 2 / 3 & \text { 観測点名 } \\ p(\cdot), p^{*}(\cdot) & \text { 確率密度関数 } \\ P_{V} & \text { 粒子が検査空間内に存在する確率 } \\ q & \text { 粒子の発生強度 } \\ q_{i}^{*} & i \text { 番目の観測点から放出したトレーサーの発生強度 } \\ q_{s} & \text { 環境污染物質の発生強度 } \\ q_{s, i} & i \text { 番目の観測点からのトレーサー拡散に基づく推定発生強度 } \\ s(\cdot), s^{*}(\cdot) & \text { 単位体積あたりの粒子の滞在時間期待值 } \\ t, t^{*}, t_{1}, t_{2}, t_{3} \text { 時刻あるいは時間差 } \\ T & \text { 粒子が検査空間内に留まる平均的時間 } \\ V & \text { 検査空間の体積 } \\ u, v & \text { 平均速度ベクトルの } x, y \text { 方向成分 } \\ x_{s}, y_{s} & \text { 環境污染物質の発生源位置ベクトルの } x, y \text { 方向成分 } \\ x_{o, i}, y_{o, i} & i \text { 番目の観測点の位置ベクトルの } x, y \text { 方向成分 } \\ \gamma & \text { 環境污染物質の拡散係数 } \\ \sigma & \text { プルームモデルにおける濃度の拡散幅 } \\ \widetilde{\mathbf{u}}, \widetilde{\mathbf{u}}^{*} & \text { 瞬時速度ベクトル } \\ \mathbf{u}, \mathbf{u}^{*} & \text { 乱れ速度ベクトル } \\ \mathbf{U}, \mathbf{U}^{*} & \text { 平均速度ベクトル } \\ \mathbf{x}, \mathbf{x}_{1}, \mathbf{x}_{2} & \text { 位置ベクトル } \\ \mathbf{x}_{o}, \mathbf{x}_{o, i} & (i \text { 番目の) 観測点の位置ベクトル } \\ \mathbf{x}_{s} & \text { 環境污染物質の発生源位置ベクトル }\end{array}$

\section{参考文献}

1) M. N. Ozisik, H. R. B. Orlande: Inverse heat transfer, Taylor and Francis, 2000

2) T. F. Zhang, Q. Chen: Identification of contaminant sources in enclosed environments by inverse CFD modeling, Indoor Air, vol. 17, no. 3, pp. 167-77, 2007.6

3) G. T. Csanady: Turbulent diffusion in the environment, Springer, 1973

4) M. A. Islam: Application of a Gaussian plume model to determine the location of an unknown emission source, Water. Air. Soil Pollut., vol. 112, no. 3/4, pp. 241245,1999

5) N. K. Ala, P. A. Domenico: Inverse analytical techniques applied to coincident contaminant distributions at Otis Air Force Base, Massachusetts, Ground Water, vol. 30, no. 2, pp. 212-218, 1992.3

6) S. Alapati, Z. J. Kabala: Recovering the release history of a groundwater contaminant using a non-linear least-squares method, Hydrol. Process., vol. 14, no. 6, pp. 1003-1016, 2000.4

7) S. M. Gorelick, B. Evans, I. Remson: Identifying sources of groundwater pollution: An optimization approach, Water Resour. Res., vol. 19, no. 3, pp. 779-
$790,1983.6$

8) 石田義洋, 加藤信介, 樋山恭助: 定常流れ場における非定常濃度応答計算 法: 第 3 報-センシング情報を用いた応答係数法に基づく環境影響物質の発 生源同定法, 空気調和・衛生工学会論文集, no. 158, pp. 1-14, 2010.5

9) 半場藤弘, 安部諭, 北澤大輔, 加藤信介: 点源放出の 1 次元拡散方程式の 逆問題, 生産研究, vol. 63 , no. 1, pp. 69-73, 2011

10) 安部諭, 加藤信介: リバースシミュレーションにおける数值安定性確保 についての研究, 日本建築学会環境系論文集, vol. 75, no. 656, pp. 891-897, 2010.10

11) 小林光, 加藤信介,村上周三: 不完全混合室内における換気効率・温熱環境 形成効率評価指標に関寸る研究：第 1 報-CFD に基づく局所領域の換気効 率評価指標の開発，空気調和・衛生工学会論文集, no. 68, pp. 29-36, 1998

12) G. W. Clark, S. F. Oppenheimer: Quasireversibility methods for non-well-posed problems, Electron. J. Differ. Equations, vol. 1994, no. 8, pp. 1-9, 1994

13) M. Bady, 加藤信介, 黄弘: Identification of pollution sources locations in outdoor environments using reverse simulation (part 1) Basics of reversed time marching method, 生産研究, vol. 61, no. 1, pp. 45-54, 2009

14) 安部諭, 加藤信介：拡散源特定を目指したリバースシミュレーション実 現のためのフラックスへのフィルター操作による数值安定性確保について の研究, 日本建築学会環境系論文集, vol. 76, no. 662, pp. 431-438, 2011.4

15) S. Abe, S. Kato, F. Hamba, D. Kitazawa: Study on the dependence of reverse simulation for identifying a pollutant source on grid resolution and filter width in cavity flow, J. Appl. Math., vol. 2012, pp. 1-16, 2012

16) A. Keats, E. Yee, F.-S. Lien: Bayesian inference for source determination with applications to a complex urban environment, Atmos. Environ., vol. 41, no. 3, pp. $465-479,2007.1$

17) R. M. Neupauer, J. L. Wilson: Adjoint method for obtaining backward-in-time location and travel time probabilities of a conservative groundwater contaminant, Water Resour. Res., vol. 35, no. 11, pp. 3389-3398, 1999.11

18) J. A. Pudykiewicz: Application of adjoint tracer transport equations for evaluating source parameters, Atmos. Environ., vol. 32, no. 17, pp. 3039-3050, 1998.9

19) F. Hourdin, O. Talagrand: Eulerian backtracking of atmospheric tracers. I: Adjoint derivation and parametrization of subgrid-scale transport, Q. J. R. Meteorol. Soc., vol. 132 , no. 615 , pp. $567-583,2006.1$

20) T. Kaminski, M. Heimann, R. Giering: A coarse grid three-dimensional global inverse model of the atmospheric transport: 1. Adjoint model and Jacobian matrix, J. Geophys. Res., vol. 104, no. D15, p. 18535, 1999.8

21) S. Houweling, T. Kaminski, F. Dentener, J. Lelieveld, M. Heimann: Inverse modeling of methane sources and sinks using the adjoint of a global transport model, J. Geophys. Res., vol. 104, no. D21, p. 26137, 1999.11 


\title{
SOURCE IDENTIFICATION OF ENVIRONMENTAL POLLUTANTS BASED ON TRACER DISPERSION IN REVERSED FLOW FIELD
}

\author{
Hideki KIKUMOTO * Ryozo OOKA** and Shinsuke KATO *** \\ * Research Assoc., Institute of Industrial Science, The University of Tokyo, Ph.D.(Eng.) \\ ** Prof., Institute of Industrial Science, The University of Tokyo, Ph.D.(Eng.) \\ *** Prof., Institute of Industrial Science, The University of Tokyo, Dr.Eng.
}

When the concentration of an aerial pollutant is detected at some observation points in an urban or built environment, immediate source identification allows for application of effective measures to decrease the concentration of the pollutant and its adverse effects. In this case, source identification involves determination of the source position and source strength from measured concentrations.

We propose a novel method for identifying the source of an environmental pollutant continuously released from a point source in a turbulent flow field at a statistically steady state. The method employs the analysis of tracer dispersion released from observation points of the pollutant in a reversed flow field (RFF). The RFF is artificially produced from the forward flow field (FFF) in which the pollutant is transported. The direction of temporal progress and velocity vectors in the RFF are created opposite to those in the FFF.

In a statistically steady turbulent flow and concentration field, the concentration of matter at a position can be expressed as a product of its source strength and expected staying time (EST) per unit volume at the position of a particle of the matter. From the discussion on the probabilistic behavior of a virtual particle in the flow fields, we found that the EST between two related points has an identical value when the release and monitoring points are interchanged in the FFF and RFF. Using the relationship of the EST and the tracer dispersion from the observation points in the RFF, the measured concentration of the pollutant and the EST give the estimated source strength as a function of the position. This property coincides with the duality of the scalar fields analytically derived in the adjoint method.

When they have multiple observation points, each tracer dispersion analysis gives different distributions of the estimated source strength However, the source strength has to have a unique point value for physical realizability. This condition reduces candidate positions of the pollutant source. When the dispersion of the pollutant occurs in the $n$-th dimensional space, the number of parameters is $n+1$, which contains $\mathrm{n}$ space coordinates of the source position and the source strength. Consequently, $\mathrm{n}+$ one observation points allow the determination of all parameters in the source identification.

This paper presents the basic idea of the source identification method based on physical consideration of the particle behavior in the RFF. An example of the source identification procedure is also presented for pollutant dispersion in a two-dimensional uniform flow field. However, the solution of source identification obtained with the present method can be very sensitive to the errors that are assumed to occur in the measurement or analysis of flow and concentration fields. For practical applications, an additional method to provide robust solutions against these errors are needed and will be considered in future studies. 